\title{
Successful treatment of Mycobacterium chelonae skin infection in a patient on long-term immunosuppressive therapy for myasthenia gravis
}

\author{
Myastenia gravis nedeniyle uzun süre immünosüpresif tedavi alan hastada \\ gelișen Mycobacterium chelonae deri enfeksiyonunun bașarılı tedavisi
}

๑ Ișıl Göğem İmren, ๑ Esra Kıratlı Nalbant*, ๑ Nermin Karaosmanoğlu*, ๑ Ömer Kutlu**, ๑ Çağrı Turan***, ๑ Pınar Celepli****, ๑ Hatice Meral Ekșioğlu*

\begin{abstract}
Pamukkale University Faculty of Medicine, Department of Dermatology, Denizli, Turkey *University of Health Sciences Turkey, Ankara Training and Research Hospital, Clinic of Dermatology, Ankara, Turkey **Ușak University Faculty of Medicine, Department of Dermatology, Ușak, Turkey ***Erzurum Regional Training and Research Hospital, Clinic of Dermatology, Erzurum, Turkey ****University of Health Sciences Turkey, Ankara Training and Research Hospital, Clinic of Pathology, Ankara, Turkey
\end{abstract}

Keywords: Mycobacterium chelonae, non-tuberculous mycobacteria, myasthenia gravis, immunosuppression

Anahtar Kelimeler: Mycobacterium chelonae, non-tüberküloz mikobakteriler, myasthenia gravis, immünosüpresyon

\section{To the Editor}

Mycobacterium chelonae ( $M$. chelonae) is a rapidly growing non-tuberculous mycobacterium (NTM) 1 . This microorganism is ubiquitous in nature, and infections in humans can be acquired from the environment by inhalation or traumatic inoculation ${ }^{1}$. M. chelonae infection may involve the skin, soft tissues, bones, lungs, and lymph nodes. Rarely, it can result in disseminated disease, particularly in immunocompromised patients ${ }^{2-4}$

Myasthenia gravis (MG) is an autoimmune disorder of the postsynaptic neuromuscular junction (NMJ) characterized by fluctuating weakness of bulbar, limb, and respiratory muscles ${ }^{2}$. It is a type 2 hypersensitivity immune response. Antibody-mediated, T-cell-dependent immunologic attack directed proteins in the NMJ. Anti-cholinesterase agents and immunosuppressant medications such as systemic steroids, azathioprine, cyclosporine, biological drugs, plasmapheresis, and intravenous immune globulin (IVIG) are the main treatment options for $\mathrm{MG}^{2}$

The 50-year-old Caucasian woman was admitted to the hospital due to lesions on her ankle that spread rapidly to her whole leg within a month. She was diagnosed with MG 14 years ago. Her medications included $75 \mathrm{mg} /$ day of

Yazışma Adresi/Address for Correspondence: Işıl Göğem Imren MD, Pamukkale University Faculty of Medicine, Department of Dermatology, Denizli, Turkey Tel.: +90 5307998583 E-posta: isil.imren@gmail.com Geliş Tarihi/Received: 17.07.2020 Kabul Tarihi/Accepted: 10.11.2020 ORCID: orcid.org/0000-0002-9574-3231

(C) Telif Hakkı 2021 Deri ve Zührevi Hastalıklar Derneği 
deflazacort and $300 \mathrm{mg} /$ day of pyridostigmine bromide for MG and gliclazide and vildagliptin for diabetes mellitus. She did not have a fever or weight loss. Her systemic examination and chest radiography findings were normal. Inspection of the lower extremities showed multiple, nontender, erythematous-purplish, round nodular lesions with a diameter of 1.5-2.0 cm spreading along the anterior and posterior sides of both legs and hips (Figure 1). She did not have any local trauma history and gardening activities. During the past month, she increased her MG drug doses to 90 and $420 \mathrm{mg} /$ day for deflazacort and pyridostigmine, respectively, because of increased muscle weakness and overwhelming symptoms. Laboratory investigations showed no abnormalities on complete blood count, biochemical, and urine tests. Multiple punch biopsy and tuberculosis, fungal, and bacterial cultures from the skin were performed to consider atypical mycobacterial infections, sporotrichosis, erythema induratum, subcutaneous sarcoidosis, subcutaneous panniculitis-like T-cell lymphoma and primary cutaneous large B-cell lymphoma, and leg type in the differential diagnosis. Histopathology showed an inflammatory infiltrate in the upper dermis, micro abscess formation, and poorly formed granulomas, including Langhans giant

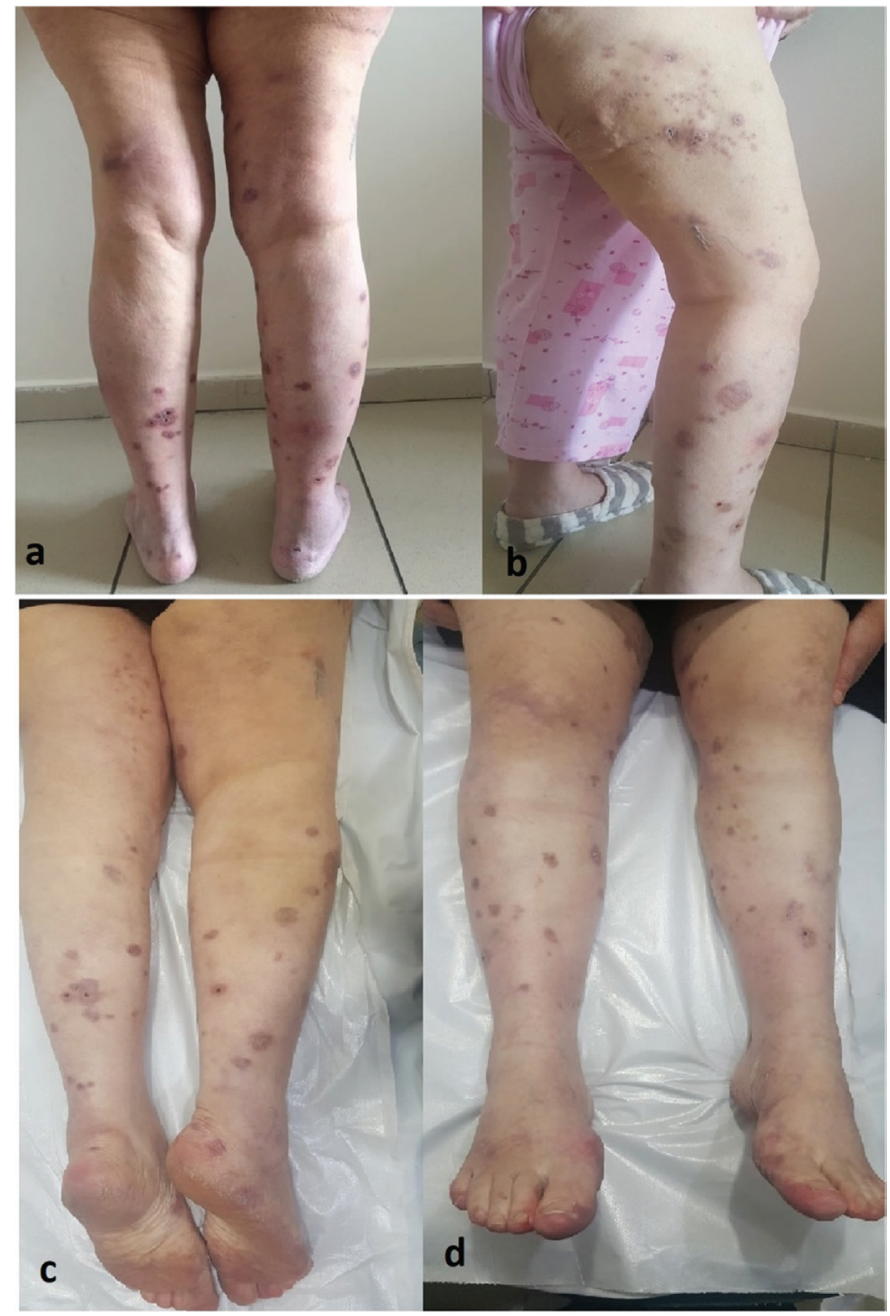

Figure 1. Multiple, erythematous-purplish, round nodular lesions with a diameter of 1.5-2.0 cm, were distributed along the anterior and posterior sides of both legs $(\mathbf{a}, \mathbf{b})$. Residual nodularity and postinflammatory pigmentation at the end of the antibiotic treatment $(\mathbf{c}, \mathbf{d})$

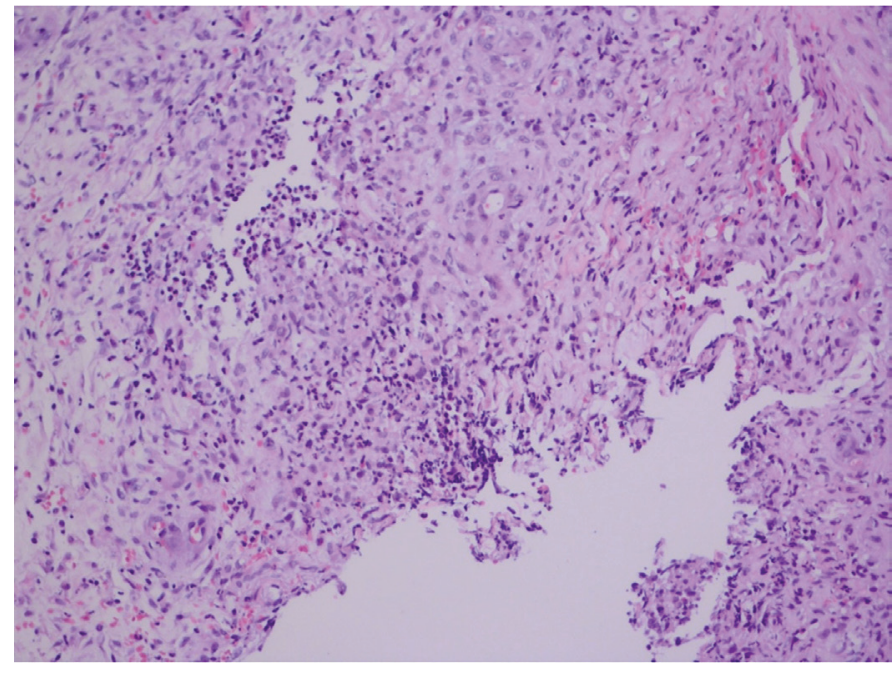

Figure 2. Inflammatory infiltrate in the upper dermis, micro-abcess formation, and granulomas, including Langhans giant cells and epithelioid histiocytes (hematoxylin and eosin staining, x100)

cells and epithelioid histiocytes (Figure 2). Non-pigmented colonies appeared on media on the $6^{\text {th }}$ day of microbiological cultivation. This isolate was identified as $M$. chlonea by partial sequencing of the $r p o B$ gene in a microbiology laboratory. IVIG infusion was started by her neurologist as a bridge therapy to minimize glucocorticoid use, and noticeable symptomatic improvement was observed. IVIG was preferred as a rapid-acting therapy in the treatment of MG symptoms because it lacks immunosuppressant effects. Dual combination therapy, including two doses of clarithromycin $500 \mathrm{mg}$ and moxifloxacin $400 \mathrm{mg} /$ day, was started for mycobacterium treatment and was continued for six months. No severe side effects were observed during the treatment. The lesion showed marked improvement after one month of therapy. Some residual nodularity and post-inflammatory pigmentations were noted in the clinical follow-up, but no evidence of active infection was found after the antibiotic treatment (Figure 1). At six months after cessation of antibiotics, there was no sign of recurrence.

Since $M$. chelonae infection has no pathognomonic findings, clinicians, pathologists, and microbiologists should collaborate for diagnosis. Several conditions such as endocrine abnormalities, infections, stress, and some drugs may exacerbate one's risk due to MG. Prolonged immunosuppressive therapy may increase susceptibility to infection ${ }^{5,6}$. Previous case reports have shown that inflammatory diseases and prednisolone use are associated with risk for NTM infections ${ }^{24}$. We presented a patient who was followed up in remission using steroids with the indication of MG but relapsed in neurological complaints due to opportunistic infection caused by the immunosuppressive adverse effect. A combination of antimicrobial therapy is recommended for a minimum of four months to prevent resistance by mutations ${ }^{2-5}$. As in other reports, moxifloxacin combined with clarithromycin was preferred in our case ${ }^{2-5}$. In literature, $M$. chelonae bacteremia was detected in a patient with MG receiving long-term steroid therapy ${ }^{2}$. Although most infections involving $M$. chelonae are limited to the skin, invasive deep tissue infections and disseminated disease are common in patients with immunocompromised status ${ }^{2-6}$. The additional negative effects of diabetes on the immune system and the immunosuppressive effect of steroids increased the susceptibility of our patient to $M$. 
chelonae infection. In this patient, bridging therapy with IVIG to control MG reduced the need for steroids and broke the vicious cycle of immunosuppression and infection. Our case report highlights that achieving good outcomes depends on early detection and rapid initiation of appropriate treatment.

The patient involved in this study gave her written informed consent authorizing use and disclosure of her protected health information.

\section{Ethics}

Informed Consent: The patient involved in this study gave her written informed consent authorizing use and disclosure of her protected health information.

Peer-review: Externally peer-reviewed.

\section{Authorship Contributions}

Surgical and Medical Practices: I.G.I., E.K.N., H.M.E., P.C., Concept: I.G.I., H.M.E., Design: I.G.I., H.M.E., Data Collection or Processing: I.G.I., N.K., E.K.N., Ç.T., Ö.K., P.C., Analysis or Interpretation: H.M.E., Literature Search: E.K.N., Ç.T., Ö.K., Writing: I.G.I., N.K.

Conflict of Interest: No conflict of interest was declared by the authors.
Financial Disclosure: The authors declared that this study received no financial support.

\section{References}

1. Pinto-Gouveia M, Gameiro A, Ramos L, et al: Mycobacterium chelonae is an ubiquitous atypical mycobacterium. Case Rep Dermatol 2015;7:207-11.

2. Samaddar A, Srivastava S, Khan S, et al: Mycobacterium chelonae bacteraemia in a patient with myasthenia gravis receiving long-term steroid therapy. Access Microbiol 2019;1:e000069.

3. Chat VS, Kearns DG, Uppal SK, Wu JJ: Risk of atypical mycobacterial infections in psoriasis patients during IL-17 inhibitor therapy. J Dermatolog Treat 2019-12:1-2.

4. McCallum C, Johnson B: Mycobacterium chelonae bacteremia in a patient taking infliximab and prednisone. CMAJ 2016;188:E538.

5. Lee WJ, Kang SM, Sung $H$,et al: Non-tuberculous mycobacterial infections of the skin: a retrospective study of 29 cases. J Dermatol 2010;37:965-72.

6. Ulusoy E, Karaca NE, Aksu G, Çavuşoğlu C, Kütükçüler N: Frequency of Mycobacterium bovis and mycobacteria in primary immunodeficiencies. Turk Pediatri Ars 2017;52:138-44. 